\title{
The story of the only (?) megalith grave on Gotland Island
}

\author{
Helene Martinsson-Wallin, Paul Wallin \\ Department of Archaeology and Osteology - Gotland University, SE \\ helene.martinsson-wallin@hgo.se \\ paul.wallin@hgo.se
}

\begin{abstract}
In this paper, we discuss the easternmost material expression of the Funnel Beaker Culture - a megalith grave on the west coast of Gotland Island in the Baltic Sea. The people who built and used the megalith brought the Neolithic lifestyle to Gotland. The biography of this monument includes two excavations, of which we participated in the latest in 1984. Our osteological analysis confirms that some thirty individuals of both sexes and various ages were buried there. The structure of the monument is that of a rectangular dolmen. This paper discusses the discovery of this specific site, and explores the existence of this type of monument in a Gotland context. Furthermore, is this really the only megalith on Gotland, or are more of these structures yet to be recognised? Finally, one may ask if the Neolithic way of life really was successful on Gotland..
\end{abstract}

IZVLEČEK - V članku analiziramo najbolj vzhoden materialni izraz kulture lijakastih čaš - megalitski grob na zahodni obali Gotlanda na Baltskem morju. Ljudje, ki so ga zgradili, so na Gotland prinesli neolitski način življenja. V biografijo spomenika sta vključeni dve izkopavanji. Pri zadnjih leta 1984 smo sodelovali. Naše osteološke analize so potrdile, da je bilo tam pokopanih približno trideset oseb obeh spolov in različnih starosti. Spomenik je oblikovan kot pravokotni dolmen. Predstavljamo odkritje tega posebnega mesta, kjer smo raziskali nastanek tega spomenika na Gotlandu. Vprašamo se, ali je to edini megalit in ali jih je mogoče na Gotlandu prepoznati več? Lahko se vprašamo tudi, ali je bil neolitski način življenja na Gotlandu uspešen.

KEY WORDS - Gotland; Early Neolithic; megalith grave; dolmen; Funnel beaker culture

\section{Gotland Island and the Neolithic process}

Gotland Island is the largest island in the Baltic Sea. It was first populated $c$. 9000 years ago by huntergatherers whose subsistence was based on a marine diet in which seal and fish played a central part. Due to isostatic uplift, the land area of Gotland increased with time. The Island rose more rapidly in the north than in the south. During the Early Neolithic time frame, $c .4000-3300 \mathrm{BC}$, the land area had become extensive (Fig. 1) and contained larger areas for pasturage and/or farming than before, even if the landscape also contained many lakes and water ways. An abundance of stone axes has been found especially on the western side of Gotland as surface finds during ploughing on light soil areas - which date to the Late Mesolithic (Fig. 2). The interpretation is that the increase in axe finds indicates largescale forest clearing (Österholm 1989.20). This is also supported by pollen diagrams (Österholm 1989. 16-17). About ten sites (Fig. 1) featuring Early Neolithic pottery, (Funnel Beaker Pottery) have been found on Gotland. As is seen in Figure 1, the sites are situated on the west part of the island, mainly on light soils that are suitable for farming and pasture land. It is likely that the Neolithic way of life and the megalith grave concept were brought in as novelties to Gotland by a population group who migrated here during the Neolithic. Towards the middle Neolithic (3300-2300 BC), the salinity of the 


\begin{tabular}{ll} 
Early Neolithic & c. $4000-3300$ BC \\
\hline Middle Neolithic & c. $3300-2300$ BC \\
\hline Late Neolithic & c. $2300-1700$ BC
\end{tabular}

Tab. 1. The Neolithic in Scandinavia (calibrated values).

Baltic Sea increased, which again favoured marine resources and subsistence based on seal hunting and sea fishing. At this time, Gotland was settled by people who made so-called Pitted Ware Pottery. The Pitted Ware groups lived from hunting seal, fish and sea birds. However, they continued to make pots, and were familiar with domesticated animals such as pig (probably almost wild), cattle and goat/sheep; in other words, having a sub-Neolithic subsistence pattern. Sedentary occupation in Pitted Ware settlements is suggested, including extensive cemeteries (Österholm 1989). However, extensive investigations of the Pitted Ware site at Ajvide (Burenhult 2002) have rendered data that could point to the fact that the Pitted Ware site cemetery was placed in a secluded ritual landscape close to the sea, and the domestic landscape is therefore yet not fully understood. Österholm, who carried out in-depth studies of the Pitted Ware sites, favoured an explanation whereby Pitted Ware groups lived by the coast, but to some extent also used the hinterland as resource procurement areas (Österholm 1989.166; Carlsson 1998.59). Whether the Pitted ware groups were descendants of the initial Mesolithic hunter-gatherer groups who still remained on the Island, or came as a new population on the island is still to be discussed. This discussion arose in the wake of recent DNA studies on Neolithic populations from Gotland and the mainland carried out by Malmström et al. (2009). These analyses indicate that the the Pitted Ware population on Gotland are closely related to modern populations in the eastern Baltic region. The ancient DNA research by Malmström et al. (2009) supports hypotheses that propose Neolithic or post-Neolithic population replacement in Scandinavia. The researchers indicate that the megalith builders probably originated from farming groups from areas of southern Europe. Of special importance, according to the genetic studies, was the ability to tolerate lactose, and the studies indicate that the current population in Scandinavia originate from these south European farmers who were mainly lactose tolerant (Malmström et al. 2009).

However, this raises questions about the population of Gotland, since the megalith tradition seems to have been less pronounced there. Did the Pitted
Ware population migrate, or disappear in other ways, and subsequently make way for yet another population group from the south known as the Battle Axe culture? The Late Neolithic migration and who lived on Gotland at the time is a question beyond the scope of this paper. However, the aim of this paper is to present the results of the only secure and investigated megalith tomb on Gotland. The people who built and used this structure brought a Neolithic lifestyle to the Island, and there are still many questions as to who these people were and whether they spread and survived there.

\section{The Megalith Grave at Ansarve, Tofta Parish, Gotland}

A megalith structure can be described as a collective grave built of large stones usually erected on end, close together, and covered with one or more cap stones, thus forming an inner chamber where corp-

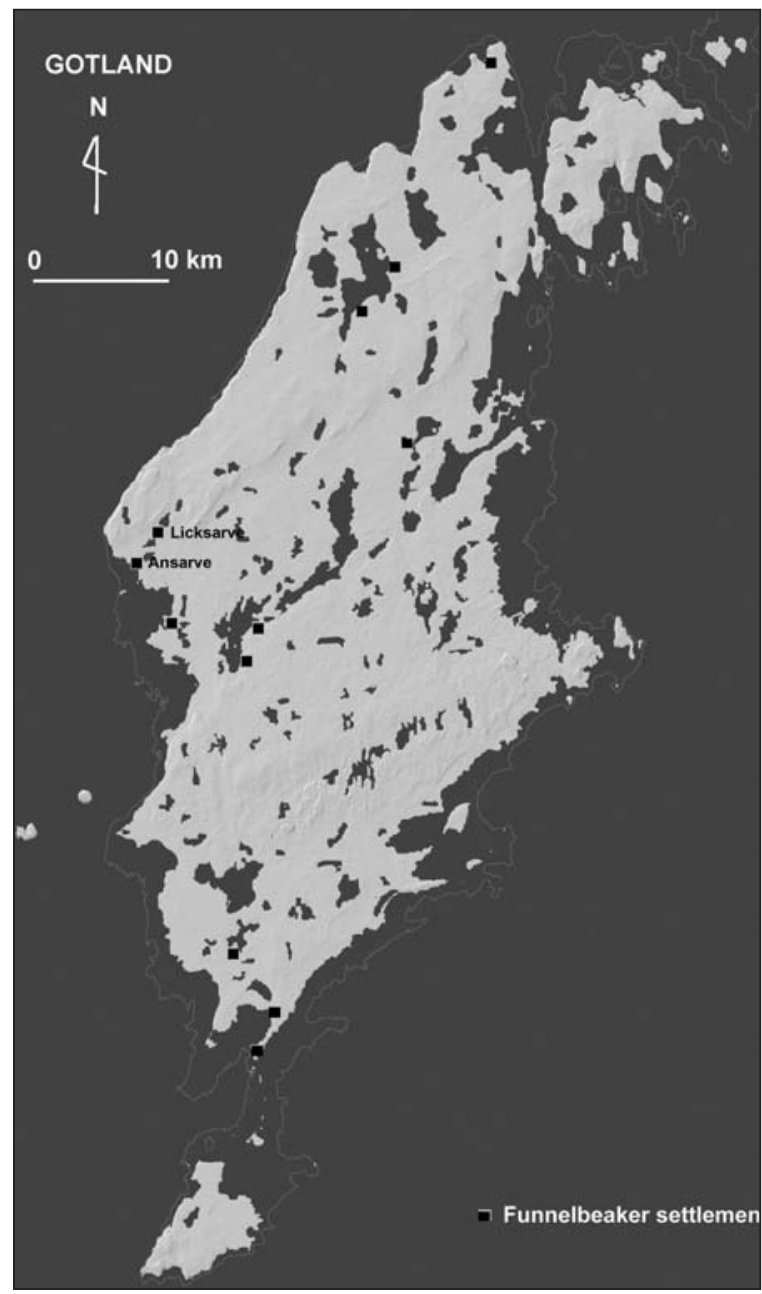

Fig. 1. Map of Gotland Island during the Scandinavian Early Neolithic, with the location of the Ansarve megalith, the possible megalith at Licksarve, and other Funnel Beaker Settlements. 


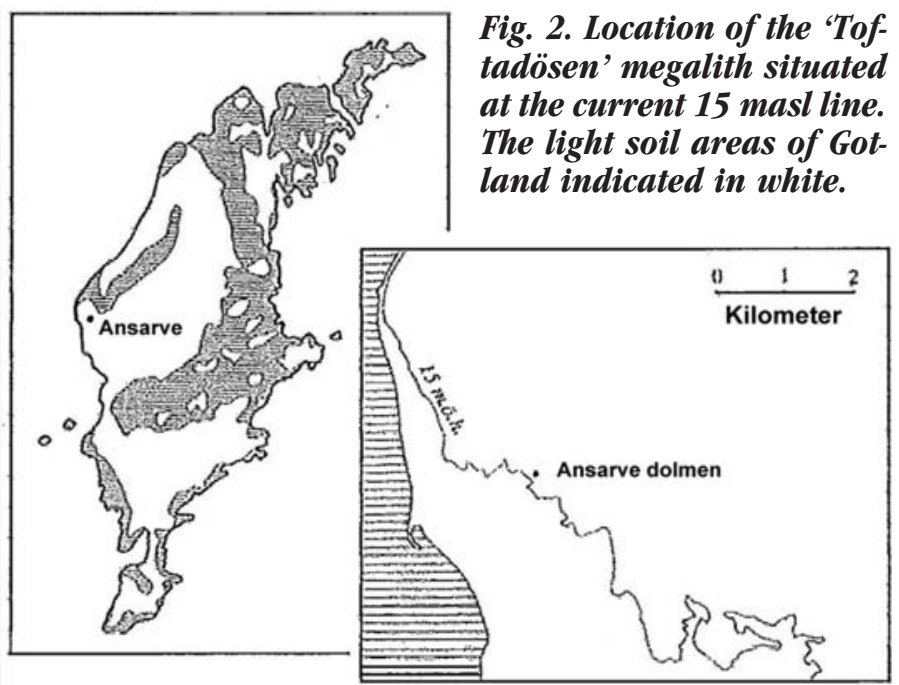

recognised as being a megalith. It is situated close to two of the largest Bronze Age stone ship settings on the Island, which makes up one of Gotland's main archaeological tourist sites. The County Administration have set up a board which gives information about the stone ship settings and Bronze Age society, and as a small remark at the end of the text, the 'possible' megalith structure situated on the other side of the narrow road is mentioned: "...if it really is a Megalith, it is the most Eastern megalith structure found in Northern Europe". In the Swedish archaeological digital site inventory, FMIS (hosted by the National Board of Antiquities), the grave is descrises were deposited. They were collective graves for an extended family or corporate decent group, and used over an extensive period. Such graves are found mainly in Western and Northern Europe (Portugal, Spain, France, Britain, Ireland, West Germany, Denmark and Sweden). They are often located close to the coast, and in Scandinavia they are often associated with a Neolithic way of life, including cultivation, domesticated animals and a certain type of pottery (Funnel Beaker Pottery). They usually have initial dates to the Scandinavian Early Neolithic 3400-3300 BC.

The only megalith construction on Gotland (Fig. 3) which archaeological excavations confirm as being such a structure is located on the western part of the Island, in Tofta Parish, about $20 \mathrm{~km}$ south of Visby. Due to shore line displacement and isostatic uplift, it is situated about $1 \mathrm{~km}$ from the current coastline, beside the road leading to the old fishing camp-site at Gnisvärd (Fig. 2). When it was built and used, it was located directly on the shore. Today, the grave consists of four 1.2 metre high granite blocks. Three stones make up the wall of the chamber on the northern side (Fig. 4). Approximately $1.5 \mathrm{~m}$ to the south stands a single large block, which comprises the southern wall of the same chamber. There are vertical entrance stones on the east corner side of the chamber, and the grave is bounded by a rectangular outline of limestone slabs bordering a stone pavement which surrounds the chamber stones. Based on its typological features, this structure is interpreted as a rectangular dolmen dating to the end of the Scandinavian Early Neolithic $c$. 3400-3300 BC (Bägerfeldt 1992.7).

Despite the archaeological excavations and their conclusive results, the structure is still not entirely bed as a 'stone setting', with a cist/chamber, and it is not indicated as a dolmen. The description was written in 1976, is vague, and has not been updated since, although earlier (1912) and subsequent (1984) archaeological investigations have been carried out at the site.

Several archaeological excavations have been carried out on both the megalith and the stone ship settings at this important prehistoric site, but the results have not really been placed in a context together, since the structures have been treated separately, due to their disparate chronology. In a way, the narrow road which divides the large stone ship settings and the megalith structure today also divide this site, even though the remains are only thirty metres apart. However, the site, including all the remains, is collectively known as Ansarve hage (pastureland). It must have been an important ritual site, since monuments of a ritual nature from various periods are located here, and re-use of the dolmen is also indicated. It appears as if the stone ship settings are 'moored' at the megalith structure, and in doing so, they are both attached to an ancient important

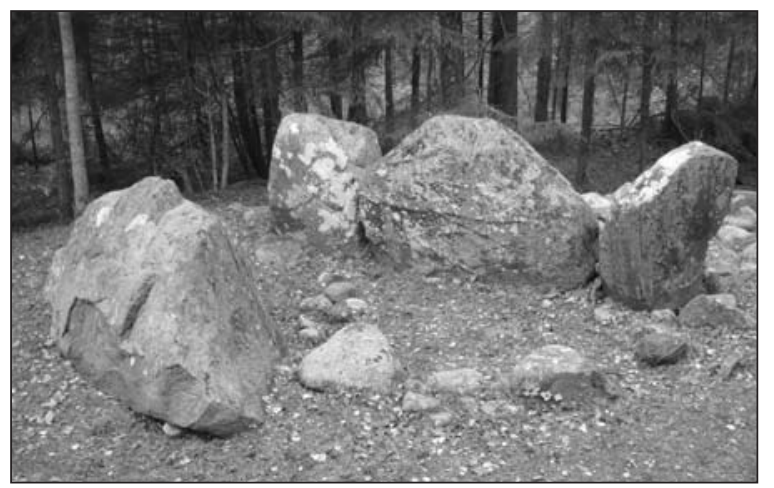

Fig. 3. The current state of the megalith at Ansarve (photo Paul Wallin). 
place, but also, due to the monumentality of the ships, distract attention from the older site.

The megalith: discovery, description, excavations and results

The megalith was first 'discovered' in the early 1900s by an army doctor, Karl Bolin. He and a head-teacher, Hans Hansson, excavated the site in 1912. They excavated (scooped out!) (Fig. 5) the chamber and found three human lower jaw bones, which according to Nils Lithberg (1914.94) they collected from this excavation. They also mentioned a smaller cist inside the chamber made from sandstone plates (Lithberg 1914.94). Such internal structures are common in megalithic graves on the mainland (Blomqvist 1989). Based on the geographical dispersal of flint artefacts on the Island of Lithberg, it was concluded that "As regards finding such megalithic graves on this island, this is the ultimate spot" (Lithberg 1914.94).

A few notes on the excavation from 1912 are included in Lithberg's dissertation Gotlands stenålder (The Stone Age of Gotland, 1914), and additional information on bone remains from the site was discovered by Lindqvist in 1990s (1997). We recently rediscovered a note on these bones in a museum storeroom, which states, "Tofta parish, Ansarve hage, 3 graves with unburned bones (1717 and 2511 grams) and one grave divided in three divisions of (29, 38 and 76 grams). Found at excavation in 1903. No osteological analysis. Stored in box 6818". The 1903 date is nine years earlier than the excavation by Bolin and Hansson, which might indicate that an earlier excavation may have been carried out by Bolin and Hansson, or possibly Oscar Wennersten, who was active at that time. However, this is speculation, and the date may simply be a later error.

It was not until 1984 that the next archaeological investigation was carried out at the site. A re-excavation was initiated by Göran Burenhult within the project 'Archaeological prospecting methods', which was linked to Inger Österholm's project 'Stone Age Gotland'. The excavation was carried out by students from Stockholm University, including the authors of this paper (Wallin and Martinsson-Wallin 1997). The aim of the investigation was to "shed light on whether the megalith tradition had been adopted on Gotland" (Bägerfeldt 1992.7).

The structure consisted of a rectangular chamber (approx. $1.5 \mathrm{x} 3 \mathrm{~m}$ ) of four granite boulders on edge

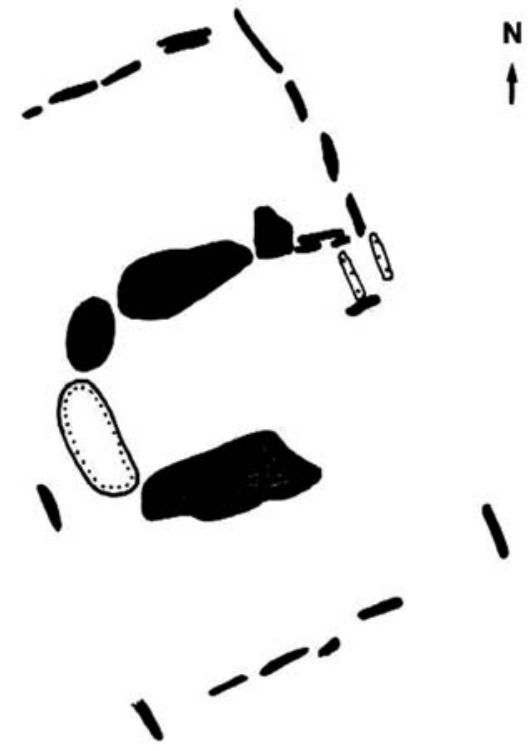

Fig. 4. Plan drawing of the Megalith at Ansarve. The dark stones are the boulders making up the structure today; the dark stones on the edges outline the pavement surrounding the megalith stones. $A$ boulder which was removed is indicated in an outline; the two threshold stones at the dolmen entrance are dotted.

(Fig. 3). One of the side stones and the cap stone are missing, but according to oral tradition, at least, the cap stone was removed to a nearby farm, probably during the second half of the $19^{\text {th }}$ century ( Lithberg 1914.94). The chamber is surrounded by a rectangular frame (approx. $5 \times 7 \mathrm{~m}$ ) of limestone slabs on edge (Fig. 4). The structure was interpreted as a rectangular dolmen which on typological grounds was dated to the late Early Neolithic to Middle Neolithic, c. 3600-2900 BC (Lang 1985.38-39; Bägerfeldt 1992.7-22; Wallin and Martinsson-Wallin 1997.23). It has been suggested that the impetus to build such a monument (or a group of immigrants carrying this tradition) came from the nearby Island of Öland to the south, directly from Western Scania, or possibly from Schleswig-Holstein in North Germany.

Among the interesting features found in situ in the structure are two lime stones placed on edge, indicating an entrance facing east (Fig. 6). A rectangular slab of sandstone with zigzag ornamentation was also found close to the short side enclosure (Bägerfält 1992.22) (Fig. 7). The artefacts from this excavation consist of 249 flint flakes, of which three are of south Scandinavian flint (one scraper), four stone axes (trindyxor), and four amber fragments, of which two were found in the chamber. A bronze tutulus $\mathrm{da}$ ted to Montelius period II (c. 1500-1300 BC), was also found inside the chamber. 
The main bulk of the bone remains recovered in the 1984 excavation derived from the 'scoop-out' in the 1912 excavation, found outside the chamber in the north to north-eastern sectors of the structure (Fig. $5)$. Thus there is no way of knowing in what positions the bodies were placed in the grave. The bone remains recovered in the excavation consisted of 547 teeth, and 5950 bone fragments, with the total weight of the latter being about $23 \mathrm{~kg}$ (Wallin and Martinsson 1986; 1992; Wallin and MartinssonWallin 1997). These remains were osteologically analysed and were shown to derive from a total of thirty-one individuals, of whom sixteen were adults, four juveniles, eight infants II, and three infants I. Of the adults, four could be determined as female and three male. The dental condition was generally good: only five teeth had caries, although tartar was found more frequently, and heavily abraded teeth were very common. Only a few fragments were identified as faunal remains: pig (1), seal (8), $\operatorname{dog}(3)$, and fish (4) (Wallin and Martinsson-Wallin 1997).

A subsequent inventory in the store at The Historical Museum in Stockholm in the 1990s, yielded 4371 grams of bone remains (SHM inv. 31173), which were analysed by Lindqvist (1997.362). This bone material consisted of fourteen teeth and 246 bone fragments, with the total weight of this material being 4371 grams. Lindqvist did not mention or question the discrepancy regarding the years of discovery - 1903 was indicated for these bones, as mentioned above - but took for granted that the material came from the 1912 excavation. All types of bone from the human body are represented, but fragments of the large bones are most common, and small bones such as finger and toe bones are underrepresented. Lindqvist (1997.362) was able to identify at least eight individuals among these bones. However, judging from the total MNI, this does not necessarily mean that there are individuals in addition to the thirty-one that the previous investigation indicated. The estimation is that the megalith was a collective burial site for between thirty to thirty-five individuals of both sexes and all age groups. The bones were generally in good condition, but ostephytis was found on vertebrae, scapulae and phalanges pedis. A clavicle has a cut which had healed, and some of the cranial bones are unusually thick, which according to Lindqvist (1997.364) could indicate anaemia due to tapeworm, for example, which that cause loss of vitamin B-12.

To the east of the chamber, but still within the outline of the rectangular demarcation, a complete hu-

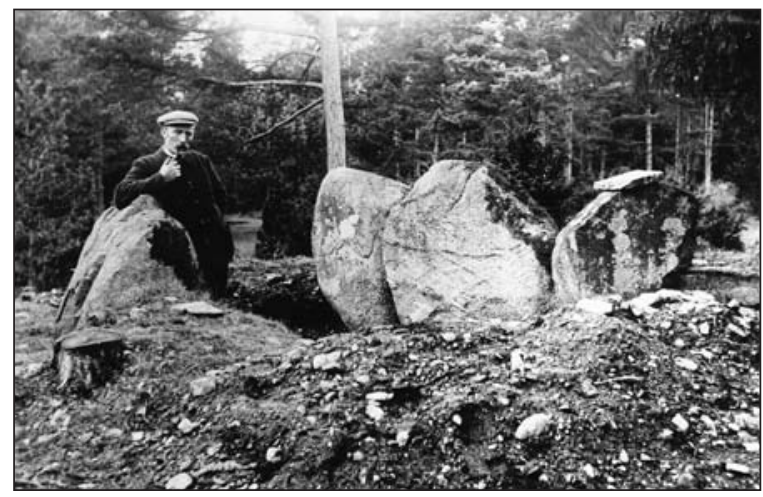

Fig. 5. Picture from the 1912 excavation (photo from Inger Österholm's collection).

man skeleton was discovered in the pavement. The remains are of a woman, aged approx. 40 years (Fig. 8 ). She was on her back, and the remains differed from others in that her dental condition was poor three molars showed traces of caries; all the lower molars on the left side were missing (pre-mortem), since the alveolus had re-ossified (closed). During reconstruction of the crushed cranium, a rounded hole was noted in the left side of the parietal bone (Fig. 9). The suggestion is that this was a trepanation, with signs of an ongoing infected healing process, which may have caused death. The skeleton was ${ }^{14} \mathrm{C}$ analysed, and dated to the late Bronze Age; if correct, this makes the burial an anomaly, since cremation was the prevailing method of disposing of the dead in this period. Trepanations occurred in Scandinavia

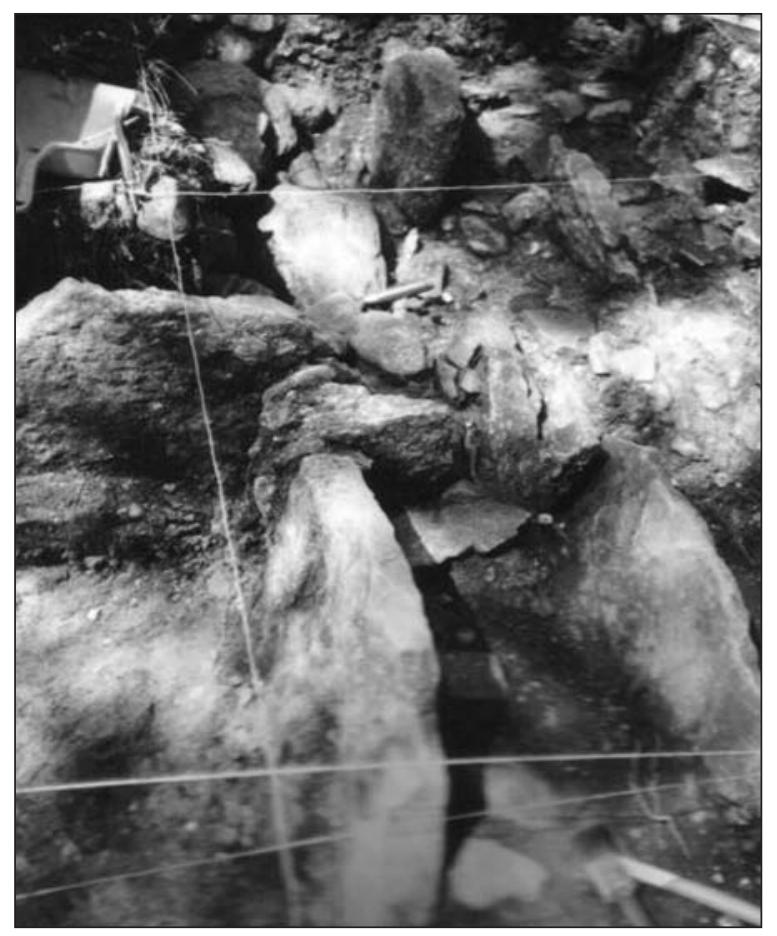

Fig. 6. Threshold stones found during the $1984 \mathrm{ex}$ cavation (photo Paul Wallin). 


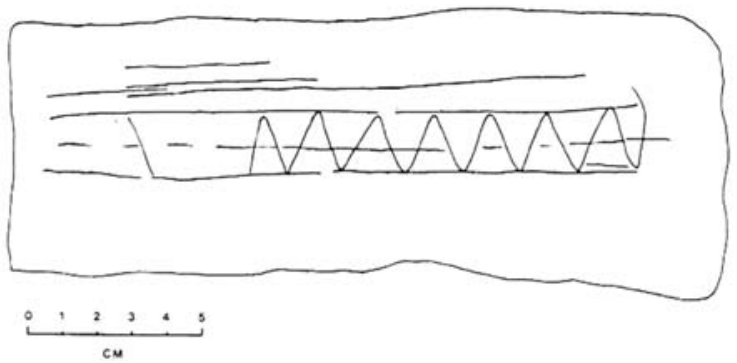

Fig. 7. Sandstone slab with zigzag pattern.

during the Neolithic, but as far as we know, they are not known in Bronze Age settings. This needs to be investigated further, and further dating of this skeleton is needed to verify the Bronze Age connection, since the date had a range of \pm 230 years, and may be erroneous. If the woman has a Bronze Age connection, this monument may have been re-used when the stone ship settings were being erected in the vicinity. The find of the bronze tutuli and the combined dating of bones from the chamber $(c$. 1980-1400 BC) are also indicative of subsequent reuse of the site. The dating of the megalith is based on six bone samples that have been radiocarbon dated. Three were carried out by conventional ${ }^{14} \mathrm{C}$ following the 1984 excavation, and three additional AMS-dates were carried out by Lindqvist on the earlier excavated material. The earliest date on mixed bone material from the 1984 excavation indicate a date to the early Bronze Age, a date in line with the bronze tutulus. A bone from the female outside the chamber indicates the late Bronze Age, which is in line with the stone ship settings erected directly adjacent to the megalith. A charcoal sample from under one of the stones indicates a date to around $\mathrm{AD}$ 500 , but seems to be out of context. However, the later AMS dates show great agreement with the typological dating of the grave type, and all three dates fall within the time frame 3300-2900 BC cal. 2 sigma. The date of the bones indicates a late Early Neolithic or early Middle Neolithic initial phase of the structure (Lindqvist 1997.356). These bones also show ${ }^{13} \mathrm{C}$ values that indicate a higher intake of terrestrial food in comparison with the analysed skeletal remains from the Pitted Ware burials (Eriksson 2004).

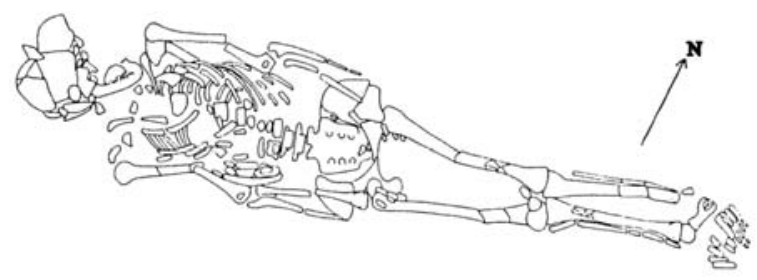

Fig. 8. Skeleton of woman found in the pavement outside the chamber.
The investigations thus suggest that this site was utilised as a burial site, and possibly for ceremonial/ ritual activities from the Late Early Neolithic/ Middle Neolithic until the Late Bronze Age. At least, the Bronze Age connection is reinforced by a stray find in the vicinity of another Bronze Age tutulus (Mn 945, SHM inv. 6207) and an Early Bronze Age cairn situated in the vicinity. This gives us another perspective on the characteristics and complexity of this site that goes beyond the scope of this paper, and which has been discussed elsewhere.

\section{Other possible megalith structures on Gotland - a detective story...}

In the early $20^{\text {th }}$ century, the archaeological literature on Stone Age sites on Gotland indicates that there may have been another megalith, situated at Licksarve farm (Fig. 1) approx. $3.5 \mathrm{~km}$ north-east of the Ansarve site (Lithberg 1914). The following was written on a photo taken by the archaeologist 0 . Wennersten, which we found in the Gotland $\mathrm{Mu}$ seum archives: "A Dolmen at Tofta, Lixarve" (Fig. 10). Further investigations in the archives and also a recent site visit have indicated that it is very likely that this was a megalith originally containing at least sixteen individuals of both sexes and various age groups (Sigvallius 2001; Wallin 2010). In the site inventory, it is described as a destroyed stone ship setting (FMIS), which are very common on Gotland, whereas megaliths are not. Documents also indicate that a farmer requested permission to remove the structure to make way for a barn, and compensation if not granted permission. The Board of National Antiquities denied his request, and compensation, but since the barn was built (see photo Fig.

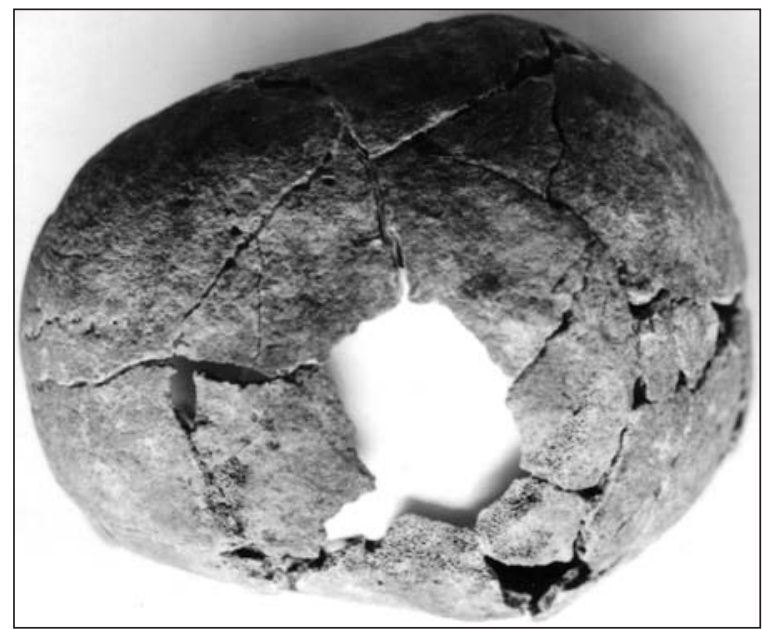

Fig. 9. Possible trepanation and infection area on the skull of a woman found in the pavement outside the chamber (photo Paul Wallin). 


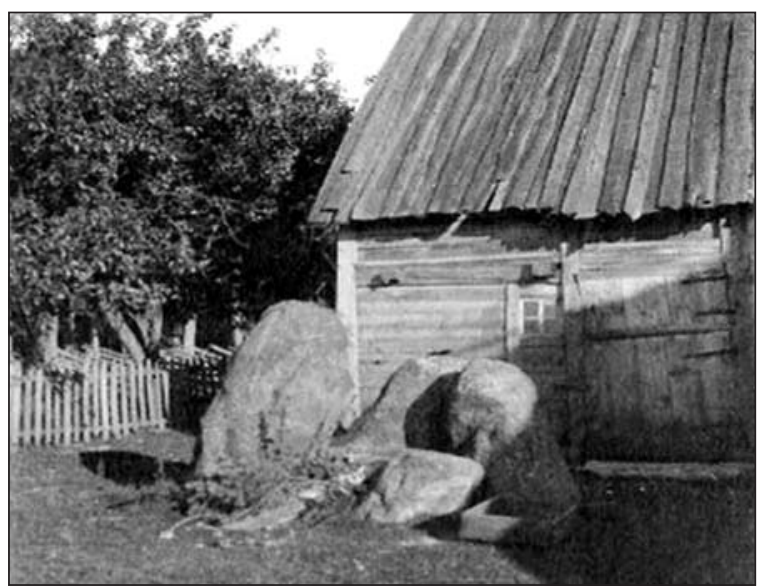

Fig. 10. Picture from the possible megalith at Licksarve (photo Gotland Museum Archives).

10), the farmer probably moved the burials found at the structure and placed them in a heap of stones some $10-15 \mathrm{~m}$ south of the megalith stones. Due to road works in 1999, the heap was excavated, revealing the skeletal remains of sixteen individuals. The bones were analysed and found to come from both sexes and various age groups, thus fitting the megalith concept of a burial site for an extended family or corporate decent group. The bones have not yet been dated, but dating could solve the puzzle. It is very likely that the farmer dared not move the actual stones, but moved the bones and surrounding pavement and heap of soil that is indicated to have been part of the structure. That the stones were surrounded by a heap of soil is indicated by a drawing in the letter to the authorities requesting the removal of the grave (Fig. 11). This discovery also poses further questions regarding other sites that feature stones of megalith dimensions that have nevertheless been classified as destroyed stone ship settings. Dating the bones from this site and re-dating the bones from the Ansarve site - as well as an inventory of 'suspicious' stone ship settings - are on the agenda for further research.

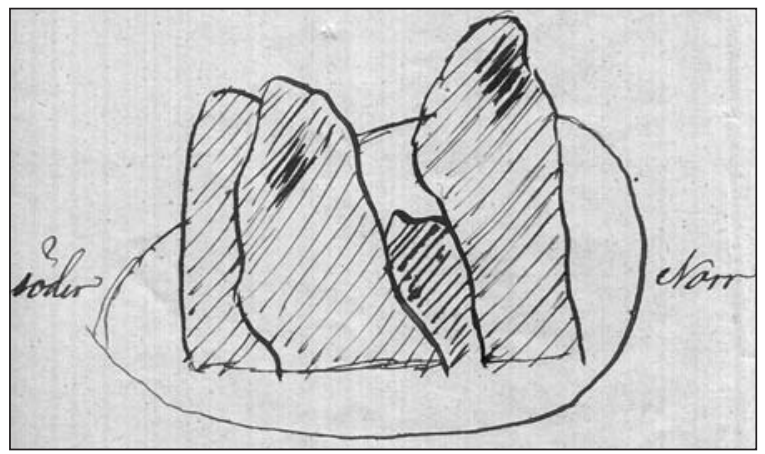

Fig. 11. Drawing of the possible megalith at Licksarve (from a letter sent to The Board of National Antiquities - ATA, Antiquarian Topographic Archive).
Megaliths and the Neolithic transition on Gotland Island - some concluding remarks

To conclude: it has now been established that there is one definite, and another very probable, megalith structure on Gotland Island, as well as at least ten locations with Funnel Beaker pottery. Both of these features are linked to the Neolithic process in Scandinavia. However, it is also possible that a complete Neolithic transition may not have occurred on Gotland, and due to the isolation of the place and the natural landscape and resources, it is likely that marine subsistence was important throughout prehistory. A combination of husbandry, small-scale farming and a hunting and gathering strategy probably prevailed even up to historical times. Gotland was populated $c .9000$ years ago, but we do not know where these groups actually originated, and if the descendants of these original settlers were still in the majority on Gotland during the Neolithic and the Bronze Age. The finds from Gotland and the ancient DNA from people who lived on the Island in the mid-Neolithic point to the fact that Gotland had various contacts and interactions throughout prehistory. So far, it has been a matter of debate as to whether the Western Megalith Culture actually did spread to Gotland, but it has been established that this way of life did so, and that it probably originated from Öland, South Eastern Scania, or the German Baltic coastal areas. There might be other locations with megaliths that could feature destroyed structures that erroneously have been defined as destroyed stone ship settings. A new inventory of this type of site is also of interest in order to carry out more detailed osteological analyses, radiocarbon dating, isotope analyses and ancient DNA sampling on excavated bone material excavated from the Mesolithic and Neolithic, and the Bronze Age. This is needed to obtain in-depth understandings of the internal and external relationships of the people who populated Gotland and to see the importance of this island in the Baltic Sea region.

\section{ACKNOWLEDGEMENTS}

We wish to thank: Göran Burenhult, who invited students to participate in a research project and inspired us to continue with these studies; the late Inger Österholm, who passed away all too soon, but supported us in various ways at Gotland University; and last, but not least, Prof. Mihael Budja, who invited us to the Neolithic seminar, which was most interesting and inspiring. 


\section{REFERENCES}

BLOMQVIST L. 1989. Sveriges megalitgravar. Theses and Papers in Archaeology 1. Stockholms Universitet.

BURENHULT G. (ed). 1999. Arkeologi i Norden. Natur och Kultur. Stockholm.

2002. Remote sensing, Vol. II. Theses and Papers in North-European Archaeology 13:b. Stockholm University. Stockholm.

BÄGERFELDT L. 1992. Neolitikum på Gotland. Problem och Konsekvenser. ARKEO-Förlaget. Gamleby.

CARLSSON A. 1998. Tolkande arkeologi och svensk forntidshistoria: Stenåldern. Department of Archaeology. Stockholm.

ERIKSSON G. 2004. Part-time farmers or hard-core sealers? Västerbjers studied by means of stable isotope analysis. Journal of Anthropological Archaeology 23: 135-162.

LANG R. 1985. Gotlands tunnackiga flintyxor. BA-manuscript paper. Stockholm University.

LINDQVIST C. 1997. Ansarve hage-dösen. Tvärvetenskapliga aspekter på kontext och den neolitiska förändringen på Gotland. In A. Åkerlund, S. Bergh, J. Nordbladh, J. Taffinder (eds.), Till Gunborg. Arkeologiska samtal. Stockholm Archaeological Reports 33: 361-378.

LITHBERG N. 1914. Gotlands Stenålder. Bagge. Stockholm.

MALMSTRÖM et al. 2009. Ancient DNA Reveals Lack of Continuity between Neolithic Hunter-Gatherers and Con- temporary Scandinavians. Current Biology 19(20): 17581762.

ÖSTERHOLM I. 1989. Bosättningsmönstret på Gotland under stenåldern. En analys av fysisk miljö, ekonomi och social miljö. Theses and Papers in Archaeology 3. Stockholms Universitet.

SIGVALLIUS B. 2001. Licksarve 2:1. Osteologisk undersökning av begravningar $i$ ett bronsåldersröse på Licksarve 2:1, Tofta socken, Gotland. Riksantikvarieämbetet. Avdelningen för Arkeologiska undersökningar. Unpublished report.

WALLIN P. 2010. Neolithic Monuments on Gotland: Material Expressions of the Domestication Process. In H. Martinsson-Wallin (ed.), Baltic Prehistoric Interactions and transformations: The Neolithic to the Bronze Age. Gotland University Press. No. 5. Visby: 39-61.

WALLIN P. and MARTINSSON H. 1986. Osteologisk analys av skelettmaterialet från megalitgraven $i$ Ansarve, Tofta Socken, Gotland. Unpublished report.

1992. Osteologisk analys. Ett sammandrag. In L. Bägerfeldt (ed.), Neolitikum på Gotland. Problem och Konsekvenser. ARKEO-Förlaget. Gamleby: 26-27.

WALLIN P. and MARTINSSON-WALLIN H. 1997. Osteological analysis of skeletal remains from a megalithic grave at Ansarve, Tofta Parish, Gotland. In G. Burenhult (ed.), Remote sensing, Vol. 1. Theses and papers in North-European Archaeology 13:a. Stockholm University. Stockholm: 23-28. 